\title{
French $\mathrm{N}$-age instrumentals: semantic properties of the base verb
}

\author{
Karen Ferret $^{1} \cdot$ Florence Villoing $^{2}$
}

Received: 2 December 2014 / Accepted: 19 September 2015 / Published online: 5 November 2015

(C) The Author(s) 2015. This article is published with open access at Springerlink.com

\begin{abstract}
The polysemy of deverbal event nouns-nominalisations-is frequently discussed in the literature. However, one interpretation associated with nominalising suffixes has never been evoked - the instrument interpretation. This paper is dedicated to the rare instrument interpretation of -age nouns (henceforth $\mathrm{N}$-age): allumage 'ignition', attelage 'harness', bandage 'bandage', embrayage 'clutch', garnissage 'garnish', gommage 'scrub', maquillage 'makeup'. We present the results of a study of instrumental $\mathrm{N}$-age nominals, based on a sample of the deverbal-age nouns collected from the TLFi. We outline the semantic conditions that determine the presence of the instrument interpretation for these nouns and argue that this interpretation is not based on semantic drift from the corresponding eventive $\mathrm{N}$-age; rather, it results from the specific properties of the morphological rule (i.e., its possible output(s)) and from the semantic properties of the input verb.

This analysis leads us to reconsider the polysemy of deverbal nouns, not as systematically based on the notion of semantic drift from a derived lexeme, but, for some interpretations, as a construct of morphological rules, given specific semantic constraints.

We conclude with a formalisation of the semantic sub-pattern within the N-age rule which generates the instrumental nominal. For the semantic representation of the base verb, we follow the theoretical framework of Levin and Rappaport (1995 and later). We incorporate this semantic formalisation in the wider representation of morphological rules envisaged in lexematic morphology.
\end{abstract}

\footnotetext{
K. Ferret

krnfrt@gmail.com

F. Villoing

Florence.Villoing@u-paris10.fr

1 Université Paris 3 \& CNRS S.F.L., 02, rue de la liberté, 93526, Saint Denis Cedex, France

2 Université Paris 10 \& CNRS Modyco, 200, avenue de la République, 92000 Nanterre, France
} 
Keywords Deverbal nouns · Instrument - Semantics · Morphological rule · Polysemy $\cdot$ French

\section{Introduction}

The polysemy of deverbal nominals, particularly the polysemy of deverbal event nominals, is treated extensively in the literature. The latest works on French nominalisation (-age, -ment, and -ion suffixation) question the binary division into event nominals vs. result nominals (Grimshaw 1990) and other interpretations, the central of which are: property, state, product, means, path, manner, location, collective, period (for an overview, see Fradin 2012a, 2012b).

Yet, one interpretation of the nominalising suffix -age (henceforth $\mathrm{N}$-age) - the instrumental reading illustrated in (1) — has never been studied. This reading is the subject of our paper.

a. Count Ns

adoucissage 'fabric softener' aiguillage 'points (on rail tracks)', allumage 'ignition', attelage 'harness', bandage 'bandage', barrage 'dam', bordage 'planking', brellage 'lashing', camouflage 'camouflage', carrelage 'tiling', chauffage 'heating', éclairage 'lighting', emballage 'packaging', embrayage 'clutch', emmaillotage 'swaddling', empaquetage 'packaging', enrobage 'coating', entoilage 'interfacing', enveloppage 'wrapping', voilage 'net curtaining'

b. Non-count Ns

blindage 'armour plating', bourrage 'stuffing', calfeutrage 'filling', capitonnage 'padding', cirage 'shoe polish', garnissage 'garnish', gommage 'scrub', maquillage 'makeup', plombage 'filling', rembourrage 'stuffing', remplissage 'filling'

The following examples show these words in context (data attested in the TLFi or online).

(2) a. Il reste à parler des barrages qui ne créent pas à proprement parler des retenues, mais qui servent principalement à dériver les eaux dans le canal d'amenée.

'The remaining topic are the dams which do not create reservoirs, strictly speaking, but which mainly serve to divert the water into the feeding canal.'

b. Le chauffeur est monté sur son siège, il a poussé l'allumage.

'The driver climbed to his seat, he pressed the ignition.'

c. De moins en moins les commerçants reprennent les emballages vides. 'Fewer and fewer merchants take back the empty packaging.'

d. Et puis maintenant, quand chéri râlera parce que mon maquillage prend tout un tiroir de la commode...

'And now, when my dearest will complain that my makeup takes up a whole drawer of the commode...' 
e. Le nouveau gommage Prada Candy est une mousse exfoliante à la texture douce et crémeuse qui adoucit la peau et affine son grain.

'The filling of the new Prada Candy is an exfoliating foam with a sweet and creamy texture that softens the skin and refines its texture.'

f. Cet emmaillotage est évidemment destiné à protéger la jeune larve des injures.

'This wrapping is clearly intended to protect the young larvae from injuries.'

g. Il met sur les tableaux un encollage et le vernis par-dessus.

'He put on the paintings a glue and the varnish above it'.

French event nominalisation with -age (3) has been the topic of numerous works aiming to identify the specific (semantic, syntactic) features of these derivations in comparison to nouns produced through other nominalisation rules, such as suffixation with -ment (4) or with -ion (5), and conversion ending with -ée (6) (Dubois 1962; Kelling 2001; Martin 2010; Ferret et al. 2010; Fradin 2012b; Uth 2010, 2011).

arrivage 'delivery', chauffage 'heating', montage 'montage'

rapatriement 'repatriation', réchauffement 'warming', débarquement 'landing'

construction 'construction', déduction, 'deduction', manifestation 'manifestation'

In this paper, we present the results of a study on instrumental $\mathrm{N}$-age nouns. We focus on the following questions:

- Which linguistic conditions determine the presence of the instrumental interpretation for N-age?

- Does such an interpretation stem from the corresponding event $\mathrm{N}$-age through semantic drift or are there specific properties required by the morphological rule?

We argue in favour of the second option, on the basis of Ferret's (2013) analysis of instrumental -oir nouns in French.

We begin with a brief presentation of the various analyses of instrumental deverbal nominals in French and in other languages, in order to determine to what extent instrumental N-age nominals corresponds to these analyses (Sect. 2).

In Sect. 3 we provide an outline of Ferret's (2013) proposal, which models the semantics of instrumental deverbal nouns in -oir on the basis of the semantic properties of the base verb. This proposal will form the theoretical basis for our approach to -age nominals, to be developed in Sect. 4. Our analysis leads us to conclude that the polysemy of deverbal nouns is not systematically based on the semantic extension or drift of a derived lexeme, but rather is a construct of the morphological rules, given specific semantic constraints, at least for some readings. We conclude with a formalisation of the semantic sub-pattern of the $\mathrm{N}$-age rule which generates the instrumental nominal. For the semantic representation of the verbal base, we follow the theoretical framework of Levin and Rappaport (1995 and later). We incorporate this semantic 
formalisation in the wider representation of morphological rules, as envisaged in lexematic morphology.

Our corpus of instrumental $\mathrm{N}$-age nouns is based on a relatively limited collection of 725 deverbal -age nouns taken from the letters A-P in the French TLFi dictionary and some neologisms found online. This limited set is due to the large number of deverbal -age nouns, which cannot be examined all at once.

While the event reading covers $100 \%$ of the corpus, the instrumental reading represents only $4.35 \%$ of cases, a similar proportion to the "means" and the "state" interpretations. Other readings are even less common (e.g., locative $2.6 \%$; garage 'garage', mouillage 'anchorage').

The instrumental $\mathrm{N}$-age nominals selected for this study were chosen on the basis of the following diagnostics of instrumental $\mathrm{N}$ (for an overview of tests in the literature, see Namer and Villoing 2008).

(i) They can head a prepositional phrase of their V-base, introduced by avec 'with'. In other words, prototypical instrumental nominals are $\mathrm{Z}$ in the structure ' $\mathrm{X}$ Vbase Y avec Z' (Cadiot 1991)

ATTELAGE: as in "Jean attèle les chevaux avec un attelage"

'John harnesses the horses with a harness'

BANDAGE: as in "Jean bande le pied de Marie avec un bandage"

'John bandages Mary's foot with a bandage'

EMBALLAGE: as in "Jean emballe le paquet avec un emballage"

'John wraps the package with packaging'

MAQUILLAGE: as in "Marie maquille Jeanne avec son maquillage de secours/personnel/de luxe"

'Mary makes Jean up with her personal/expensive make-up'

(ii) They designate artefactual objects.

\section{Theoretical approaches to instrumental deverbal nouns}

\subsection{The instrument reading and morphological rules in French}

The instrumental reading of morphological rules in Romance and Germanic languages is frequently dealt with in relation to the polysemy of agentive suffixes, but is rarely an object of study in itself. This situation is due to the fact that the instrumental reading is never the only interpretation possible for a morphological rule, since the deverbal nouns produced by these rules typically have multiple readings, particularly the agentive one.

This is true for French as well. The instrumental interpretation of the deverbal nominal in French is associated with other interpretations of the same morphological rule as illustrated by the following examples.

- -eur/-euse suffixation: As in many Romance and Germanic languages, -eur nouns can have an instrumental (8) and an agentive reading (9) (Benveniste 1966; Fradin 2005 for French): 
(8) aspirateur 'vaccum cleaner', perceuse 'drill', écouteur 'headphones', mélangeur 'mixer'

(9) danseur 'dancer', chanteur 'singer', bagarreur 'fighter'

- oir suffixation: Nouns with -oir can have an instrumental (10) and a locative reading (11) (Namer and Villoing 2008; Ferret 2013; Fradin and Winterstein 2012).

(10) hachoir 'choper', remontoire 'winder', sarcloir 'hoe'

(11) fumoir 'smoking room', parloir 'parlour', urinoir 'urinal'

- Verb-noun compounding (12) and verb to noun conversion (13).

ouvre-boîte 'can-opener', presse-citron 'lemon juicer', nettoie-vitre 'window-cleaner', ramasse-miettes 'crumb-sweeper'

réveil 'alarm clock', presse 'printing press', réchaud 'stove', rallonge 'extention'

Verb-noun compounds (Villoing 2009, 2012) and verb to noun conversions (Tribout 2010) cover the entire range of deverbal noun readings possible (Tribout and Villoing 2012, 2014). Apart from the instrumental reading, we also find agentive (14a, b), locative $(15 \mathrm{a}, \mathrm{b})$, patient $(16 \mathrm{a}, \mathrm{b})$, and finally, eventive $(17 \mathrm{a}, \mathrm{b})$ readings.

(14) a. garde-côte 'coast-guard', trouble-fête 'spoilsport', gratte-papier 'penpusher'

b. juge 'judge', garde 'guard', guide 'guide'

a. appuie-tête 'headrest', coupe-gorge 'cut-throat alley', hurle-loup (a toponym, lit. howl-wolf)

b. décharge 'dump', butée 'abutment', entrée 'entry', sortie 'exit'

a. gobe-mouton 'things that sheep swallow' (lit. swallow-sheep), broutebiquet 'honeysuckle' (lit. graze-young goat)

b. affiche 'poster', transplant 'transplant', couvée 'clutch', concept 'concept'

a. lèche-vitrine 'window-shopping', remue-menage 'commotion' (lit. move-household)

b. marche 'walk', survol 'flyover', dépose 'removal', rappel 'recall'

We mention here only these central rules, but one can add suffixation with -ette (binette 'hoe', allumette 'match') and with -on (guidon 'handlebars', torchon 'tea/kitchen towel') (see Dal 1999; Plénat 2005).

The polysemy of agentive/instrumental deverbal nouns has led to diverse treatments in the literature ranging from 19th century grammarians (Meyer-Lübke 1890; Darmesterter 1877 cited in Rainer 2005) to present-day research (see Rainer 2005 for a critical review of Haarmann 1975; Panagl 1975; Dressler 1980; Booij 1986; Ryder 1990; see also Rosenberg 2011 for a quick review of Winther 1975; Corbin and Temple 1994; Dressler 1986; Sleeman and Verheugd 2004). 
We will limit ourselves to two of these analyses, namely Corbin and Temple (1994) and Booij (1986, 2005 and 2007), ${ }^{1}$ who work within a lexematic framework similar to our own in the analysis of word formation rules.

\subsection{The semantics of morphological rules producing instrumental Ns in the literature}

The instrument reading as independent of the rule and determined by extralinguistic or socio-cultural context Corbin and Temple (1994) and Corbin (2015, to appear) assume that the agentive/instrumental polysemy of certain constructed nouns (such as verb-noun compounds, -eur suffixation) is not linguistically governed. Instead, they argue that this polysemy depends on extra-linguistic and socio-cultural constraints (as already proposed by Benveniste 1966:61 and Winther 1975:59, cited in Rosenberg 2011). So the agentive or instrumental interpretation of -eur nouns (cf. (8) and (9)) or of verb-noun compounds (cf. porte-avions 'aircraft carrier', porte-savon 'soap holder', porte-étendard 'flag bearer') does not stem from the morphological rule. Rather, the meaning of these derivations is abstract and underspecified $+/-$ human. The word formation process (the morphological rule) is associated with one very general meaning and the specific interpretation of the deverbal lexeme (as, for example, an agentive or instrumental reading) is determined by world knowledge.

$$
\begin{aligned}
& \text { porte-avions 'aircraft carrier', porte-savon 'soap holder', porte-étendard } \\
& \text { 'flag bearer' }
\end{aligned}
$$

For example, a compound like porte-avions 'aircraft carrier' denotes an object rather than an agent due to pragmatic non-linguistic reasons: a human cannot, for physical reasons, be referred to as an aircraft carrier. Similarly, porte-savon lit. 'soap holder' cannot refer to a human due to the social organisation of the world. But no linguistic property of the morphological rule prevents a verb-noun compound from denoting both an agent and an instrument, as in porte-étendard 'flag bearer'.

As shown below, this approach is weakened by recent work (Ferret 2013) showing that the semantic properties of the verbal base play a crucial role in enabling the instrumental reading of a derived nominal (see Sect. 4).

The instrumental reading as derived from the agentive reading of the rule According to some approaches, it is the individual complex word with these suffixes that shows semantic variation, and this variation follows from independently established principles of semantic interpretation (Booij 2005:222). Thus, the polysemy of these nominals is treated through multiple levels of meaning: the morphological rule defines a central prototypical or core meaning ("Personal Agent"), which corresponds

\footnotetext{
${ }^{1}$ We do not discuss Booij and Lieber's 2004 proposal since their approach to polysemy is identical to that in Booij 1986: "In fact, the analysis that we propose here is very much that of Booij (1986) and Rappaport Hovav and Levin (1992), except that we reformulate the earlier argument-structure theoretic analysis in terms of lexical semantics" (Booij and Lieber 2004:37). The advantages of the Lexical Semantics framework according to these authors do not involve the polysemy of instrumental deverbal nouns, but "first, it gives a way of talking about denominal -er forms [...] and second, it allows us finally to see how -er and -ee can come to have overlapping interpretations." (Booij and Lieber 2004:37).
} 
to the binding of the external argument of the verb, and the range of additional interpretations ("Impersonal Agent", "Instrument") is derived through meaning extension mechanisms such as metaphor and metonymy (cf. 19), established independently of the morphological formation processes.

$$
\begin{aligned}
& \text { Personal Agent }>\text { Impersonal Agent }>\text { Instrument. (Booij 1986) } \\
& \text { zender 'person who sends' > zender 'radio/TV Station' > zender 'transmit- } \\
& \text { ter' }
\end{aligned}
$$

The instrument role does not have the same status as the agent role since there are cases in which the subject argument of the verb does not allow for an instrumental interpretation, whereas the corresponding deverbal noun does allow for an interpretation as instrument noun (Booij and Lieber 2004:13). Thus, the conceptual category agent associated with derived - er nominals can be extended following extension paths that take various readings into account. The human/instrument shift is an example of a domain shift that is frequently found in natural language and can be regarded as a metaphorical chain: the notion of agent is transferred to the domain of material inanimate objects, which are viewed as agents, executing a specific task. Consequently, there is no point in assuming a list of different meanings for these deverbal suffixes.

We will show that this representation is inadequate for the analysis of French $\mathrm{N}$ age instrumentals (as well as for $\mathrm{N}$-oir instrumentals), since

(a) according to our studies, and contrary to Booij (1986 and 2005) the instrument interpretation is always linked to the lexicalisation of an instrumental participant of the base verb;

(b) none of them is associated with an agentive reading, which is not available with this suffix at all. This critique is not restricted to French $\mathrm{N}$-age, and has frequently been formulated for other languages, wherein instrumental nominals exist independently of agentive nominals or for which the agentive meaning is recorded later than the instrumental interpretation (cf. Rainer 2005:30 for Spanish and for German (citing Panagl 1975), and Rosenberg 2011 for French).

The instrument reading as derived from the morphological rule This problem is also noted by Booij (2007), who acknowledges that some instrumental nouns are not necessarily related to an agentive reading of the same lexeme.

The solution proposed in his 2007 study, couched in the Construction Grammar framework, is to replace word polysemy with rule polysemy: "it is not individual words, but also the constructional schema for deverbal -er nouns as such that has become polysemous." (Booij 2007:4). Thus, the semantic pattern associated with deverbal nominals includes an initial, hierarchically high level, 'entity involved in V', which is relatively underspecified and completed by sub-schemas that account for the various specific interpretations of -er nominals: agent of $\mathrm{V}$ (which produces personal agent and impersonal agent, through semantic derivation), instrument of $\mathrm{V}$, object of V. The instrumental sub-schema is mainly interpreted either as a case of metonymic sense extension or sometimes, as pointed out by Rainer (2005), as the result of ellipsis (appareil aspirateur $>$ aspirateur following the ellipsis of appareil) or of homonymisation due to historical coincidence. 
Representation of semantic sub-schemas of -er deverbal suffixation in Dutch (Booij 2007)

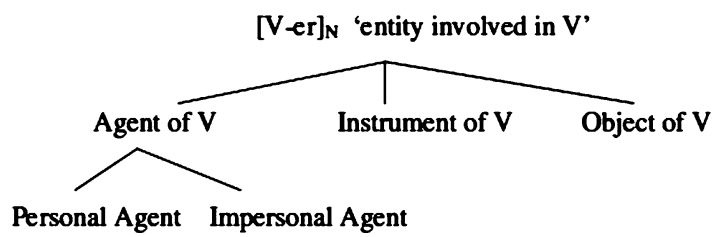

We agree that morphological sub-schemas are needed in order to account for the various meanings that deverbal lexemes may exhibit. But we are not sure that the instrumental sub-schema depends on cognitive extension schemas or on ellipsis and homonymisation.

\subsection{Hypotheses on the instrumental interpretation of $\mathrm{N}$-age}

Our research shows that the instrumental meaning (certainly like the agentive meaning or other readings), even though it is one of the options enabled by the morphological rule, can only be expressed if very specific semantic conditions are met by the base verb. Such a pattern of polysemy does not necessarily follow from a cognitive extension schema nor is it due to historical coincidence, but it does depend on semantic constraints on the verbal base and on the interpretation of the output.

We hypothesise that the semantic conditions needed to construct an instrumental noun are shared by all morphological rules in French that form a deverbal instrumental noun. Thus, the aim of this article is to demonstrate that instrumental $\mathrm{N}$-age nominals obey the same semantic constraints on the verbal base and output as instrumental N-oir nominals, despite the fact that -age suffixation does not prototypically produce instrumental nouns, unlike -oir suffixation. We therefore arrive at a representation of semantic sub-patterns for deverbal -age suffixation similar to Booij's (2007) analysis of -er deverbals, the difference being that rule-based instrumental polysemy is conditioned by the semantic properties of the base and not by cognitive extension schemas (cf. Sect. 2.2).

Consequently, we reject the hypothesis that instrumental $\mathrm{N}$-age is derived from event $\mathrm{N}$-age through semantic drift. Our position is based on a number of arguments.

(i) The French morphological rules which prototypically produce instrumental deverbal nouns show no polysemy with an eventive reading; this option is either impossible for these rules (suffixation with -oir, -eur), or very rare (verb-noun compounding).

(ii) The very small proportion of instrumental $\mathrm{N}$-age, compared to event $\mathrm{N}$-age cases makes a specific semantic derivation of $\mathrm{N}$-age event $>\mathrm{N}$-age instrument unlikely. One would expect a process of semantic drift to be much more productive, such as $\mathrm{N}$-age event $>\mathrm{N}$-age result. In contrast, specific semantic constraints on the formation of instrumental deverbal nouns naturally account for this small proportion. Indeed, this small proportion follows from the fact that, since the process is heavily constrained by conditions on both its input (semantic type of the base, which we present below) and its output (the formation of instrument 
nouns), chances that all conditions are met for an instrumental formation, are relatively low. Thus, the $\mathrm{N}$-age rule produces eventive nouns by default, and while semantic conditions on the input may be obeyed, the formation of the instrumental output remains marginal, as it does not correspond to the primary function of the rule. To illustrate, a verb like décaper 'scour' serves as the base for the derived $\mathrm{N}$ décapage 'scouring', but does not produce an instrumental reading despite the correspondence of the base to the semantic constraints on the input ([+external causation] \& [+manner], cf. Sect. 3); this reading is lexicalised by the suffix -ant (décapant 'stripper'). It therefore seems more likely to hypothesise that -age suffixation occasionally adopts a general instrumental sub-pattern which is available a priori for all deverbal instrumental nouns (N-oir, N-eur, verb-noun compounding, verb to noun conversion).

(iii) Furthermore, if there is a semantic pattern in French that allows the derivation of $\mathrm{N}$-instrument from $\mathrm{N}$-event, how do we account for the fact that simple $\mathrm{N}$-event (that is, non-deverbal Ns) never undergo such semantic drift? None of the simple event nouns (e.g., concert, crime, émeute 'riot', gala, grève 'strike', obsèques 'funeral', panne 'breakdown', procès 'trial') have an equivalent instrumental reading.

In our view, the combination of these arguments considerably weakens the hypothesis that instrumentals $\mathrm{N}$-age are derived from their eventive counterparts.

\section{Properties of deverbal Ns with an instrumental reading}

On the basis of a study of deverbal N-oir nominals in French, which denote either an instrument (rasoir 'razor', tranchoir 'slicer; chopper') or a location (lavoir, 'washing place', patinoire 'skating rink'), Ferret (2013) aims to determine (1) to which semantic properties of the verbal base the nominalisation rule is sensitive and (2) whether the interpretation of the $\mathrm{N}$-oir (instrumental or locative) correlates with semantic properties of the verb. Ferret focuses on two verbal semantic properties: causation (as defined by Levin and Rappaport 1995, 2000), which is coded by the author as [+/-external causation], and manner (in the specific sense defined by Levin 1993), coded as [+/-manner]. Ferret shows that both necessary properties play a determining role in the selection of verbal bases as input for the rule and in the instrumental or locative interpretation of the $\mathrm{N}$-oir output.

The rule constructs an instrumental $\mathrm{N}$-oir if the input verb bears both semantic features [+external causation] \& [+manner], i.e. if the input verb is causative, therefore transitive, and if its meaning specifies the manner in which the denoted event is realized-including a necessary instrument. It is this instrumental semantic participant that is lexicalised in the instrumental -oir rule.

In the following sections, we present the two semantic properties which are necessary in a verb for it to serve as input of the rule forming instrumental deverbal $\mathrm{N}$-oir: the verb needs to denote an externally caused event, and it needs to involve an instrumental semantic participant (that is, to containing the semantic component manner). 


\subsection{Verbs with internal vs. external causation}

Levin and Rappaport (1995, 2000) distinguish between internally and externally caused eventualities (verbs with internal causation and verbs with external causation, respectively). They place this semantic property of (internal or external) causation at the heart of the unergativity/unaccusativity distinction for a subgroup of unaccusative verbs: verbs alternating with a causative transitive pattern. Unaccusative verbs that do not alternate with a (causative) transitive pattern are outside of the proposed dichotomy, ${ }^{2}$ according to the authors.

Internal causation is defined by Levin and Rappaport (1995:91) as follows:

"some property inherent to the (single) argument of the verb is "responsible" for bringing about the eventuality"

Internally caused verbs are unergative: laugh, run, scream, tremble, smell.

Externally caused verbs, i.e. verbs having the semantic property of external causation, are given the following definition.

"Unlike internally-caused, externally-caused verbs, by their very nature, imply the existence of an "external cause" with immediate control over bringing about the eventuality described by the verb". (Levin and Rappaport (op. cit., p. 92)).

Some externally-caused verbs show causative alternation. These are verbs with both transitive and unaccusative syntactic patterns (23):

a. John broke the window (transitive)

b. The window broke (unaccusative)

In (23b) break is predicted to be unaccusative rather than unergative because it is an externally caused verb as defined in (22). In fact, the event structure of the verb in (23b) is derived from that of the causative transitive verb (23a) through the suppression of the external cause (a lexical operation, see Levin and Rappaport 1995 for details).

More generally, causative verbs, even those without alternation, are also externallycaused verbs (24) (see Levin and Rappaport 1995):

$$
\begin{aligned}
& \text { a. John cut the bread. } \\
& \text { b. } \quad * \text { The bread cut. }{ }^{3}
\end{aligned}
$$

\footnotetext{
${ }^{2}$ Note, however, that according to Levin and Rappaport (1995, 2000), the semantic participant of "only" unaccusative verbs (arrive, die, etc.) is not captured in this dichotomy. The only participant of these predicates is associated with an internal argument according to one of the other Linking Rules for the internal argument in Levin and Rappaport's framework. It is then subject to Linking Rules mapping the semantic participant of the event structure to an internal argument, just as for unaccusative-transitive alternating verbs under consideration here. See (25) in Sect. 3.2. for the analysis of these verbs, classified by Ferret (2013) as [-external causation]; transitive non-causative verbs (e.g., observer 'observe', traverser 'cross') are also classified as [-external causation], following Ferret and Villoing (2012) and Ferret (2013).

${ }^{3}$ We do not consider here middle constructions ('The bread cut easily'). The point is that contrary to the transitive causative verb break (23), the transitive causative verb cut does not alternate with an unaccusative pattern as shown in (24).
} 
To sum up, internally-caused verbs are unergative, while externally caused verbs are causative verbs which may either show causative alternation (break, transitive or unaccusative (23)) or not (cut, transitive only (24a)).

\subsection{Vs with +/-external causation and the interpretations of $\mathrm{N}$-oir}

Ferret (2013) proposes to encode the semantic property of causation using the feature [+/-external causation].

(25) (i) The semantic feature [+external causation] is borne by transitive causative verbs (whether or not alternating with an unaccusative pattern)

(ii) The semantic feature [-external causation] is borne by unergative verbs (internally-caused verbs in Levin and Rappaport 1995, 2000), and by extension, by unaccusative verbs not concerned by the internal/external causation distinction and by transitive non-causative verbs (the latter, following Ferret and Villoing 2012).

Her results show that the instrumental -oir rule is indeed sensitive to the semantic feature [+external causation] of the verb.

Only transitive verbs with [+external causation], i.e. causative verbs, serve as input for instrumental N-oir (rasoir 'razor'; remontoire 'winder'; sarcloir 'hoe'; tranchoir 'choper'). These are verbs whose event structure contains the external cause of the denoted eventuality, that is, causative verbs and thus transitive verbs.

However, the data indicate that a causative verb is not automatically suitable as a base for instrumental $\mathrm{N}$-oir. Thus, some causative verbs (bearing the feature [+external causation]) produce locative, but no instrumental N-oir (lavoir 'washing place', assassinoir 'lit. a place where one can be murdered/a dangerous place').

In order to account for these examples, Ferret employs another verbal semantic property: manner (in the sense of Levin 1993 and Levin and Rappaport 1995, 2000; distinct from “manner” in Talmy's sense 1975).

\subsection{The semantic component MANNER and its role in N-oir nominals}

In addition to [+external causation], the verb must contain the semantic component manner (coded by Ferret as [+manner]). This component, as defined by Levin (1993), specifies the 'causing event' by implying the obligatory participation of an instrument in the realisation of the denoted eventuality.

(26) a. "The event described by cut involves the production of an incision, something that requires the use of an instrument". (Levin 1993:10)

b. "The very meaning of the verb cut implies the existence of a sharp instrument that must be used by a volitional agent to bring about the change of state described by the verb" (Levin and Rappaport 1995:103).

According to Levin and Rappaport (1995), the manner component distinguishes verbs of the cut type from verbs of the break type, since the latter type do not specify the activity (the causing event) that leads to the realization of the denoted eventuality. So, 
the meaning of these verbs does not imply the presence of the manner component, contrary to $c u t$ type verbs. ${ }^{4}$

In order to diagnose the semantic MANNER component in the meaning of the verb, Ferret exploits Koenig et al. (2007)'s analysis of instrumental participants in the semantics of verbs.

Koenig et al. (2007) identify the obligatory presence of an instrument in the meaning of verbs. According to their definition

a. "if 'somebody beheads somebody' is true, 'she beheads him with something' and 'she uses something to behead him' are also true" (Koenig et al. 2007:182).

Elaborating on Koenig et al. (2007), ${ }^{5}$ Ferret (2013) proposes the following test to identify whether a manner component is present in the meaning of a verb:

$$
\begin{aligned}
& \mathrm{x} \text { has VP-ed } \rightarrow \mathrm{x} \text { used an object to VP (true); } \\
& \text { such as a N-Inst for example (true) }
\end{aligned}
$$

Thus, if $x$ has VP-ed is true, then $x$ used an object to VP is also true; so $x$ has VP-ed entails that $x$ used an object to $V P$. As a consequence, the two propositions expressed in the following sentence are contradictory: \# Marie a rasé la tête de Jean mais elle n'a pas utilisé d'objet pour raser la tête de Jean. 'Marie shaved Jean's head, but she didn't use an object to shave Jean's head'. By contrast, the propositions expressed in the following sentence are compatible: Marie a assassiné son amant mais elle n'a pas utilisé d'objet pour assassiner son amant 'Mary murdered her lover but she didn't use an object to murder her lover'.

This test differs slightly from that in Koenig et al. in two ways: by the use of the word "object" (= artefact) instead of "something", which is too general, and by adding "such as N-Instr, for example" intended to identify the kind of instrumental semantic participant allowed by the meaning of the verb. Any verb that passes this test is classified as [+manner]:

(29) Marie a coupé le saucisson $\rightarrow$ Marie a utilisé un objet pour couper le saucisson (Vrai), comme par exemple un couteau (Vrai) $\Rightarrow$ couper: transitive causative [+manner]

'Marie cut the sausage $\rightarrow$ Marie used an object to cut the sausage (True), such as a knife, for example (also True)' $\Rightarrow$ cut transitive causative [+manner]

If the entailment is false (30b), the verb does not lexically entail (in the sense of Dowty 1991 for proto properties entailed by verbs) an instrumental semantic participant that is necessary for the realisation of the eventuality denoted by the verb. The verb is classified as [-manner]:

$$
\text { a. Marie a frappé son chien. }
$$

\footnotetext{
${ }^{4}$ But see Levin and Rappaport (2006, 2008, 2011) for a different view on $c u t$.

${ }^{5}$ For a different use of Koenig et al.'s analysis, see Fradin and Winterstein (2012).
} 
b. Marie a frappe son chien $\rightarrow$ Marie a utilisé un objet pour frapper son chien (Faux), comme par exemple un bâton (Faux) $\Rightarrow$ frapper transitive causative [-manner]

'Marie beat her dog $\rightarrow$ Marie used an object to beat her dog (False), such as a stick, for example (False)' $\Rightarrow$ beat transitive causative [-manner]

We distinguish the ontological notion of instrument (e.g. fork, knife, stick) from the notion of an instrumental semantic participant (artefact) which is part of the meaning of the verb; only the latter is necessary for the realisation of the eventuality denoted by the verb.

Marie a frappé son chien avec un bâton.

'Marie beat her dog with a stick'

Le bâton 'the stick' in (31) is an instrument from an ontological perspective, but it is not a semantic participant lexically entailed by the meaning of the verb batter 'beat', i.e. le bâton needs not be present for the eventuality described by battre son chien 'beat her dog' to take place. One could beat one's dog with one's hands or legs, but these are not instruments in the sense intended here -a man-made object, an artefact (see Sect. 1, where we define instrument, semantic participant).

A body part is not an instrument (artefact). It is possible to murder someone by pushing them off a cliff or out of a window without having to resort to a man-made instrument. The verb assassiner 'murder' does not lexically entail the use of such an instrument (artefact). The same is true for the verb casser 'break'; one could casser un vase 'break a vase' by throwing it to the floor, by inadvertantly touching it, causing it to fall, or by using a hammer. Thus, casser does not lexically entail the use of an instrument to realise the eventuality denoted by the verb.

The test in (28), applied to the [+external causation] verbs of Ferret's (2013) -oir dataset, distinguishes two sets, verbs with both [+external causation] \& [+manner] (32) and verbs with both [+external causation] \& [-manner] (33).

Jean a assassiné sa femme $\rightarrow$ Jean a utilisé un objet pour assassiner sa femme. (false)

$\Rightarrow$ assassiner, transitive causative [-manner]

'Jean murdered his wife $\rightarrow$ Jean used an object to murder his wife (False)'

$\Rightarrow$ murder, transitive causative [-manner]

Jean a rasé la tête de Paul $\rightarrow$ Jean a utilisé un objet pour raser la tête de Paul. (Vrai) comme par exemple un rasoir. (Vrai)

$\Rightarrow$ raser transitive causative [+manner]

'Jean shaved Paul's head $\rightarrow$ Jean used an object to shave Paul's head (True), such as a razor, for example. (true)'

$\Rightarrow$ shave transitive causative [+manner]

The -oir rule constructs an instrumental N-oir if the input verb bears both necessary semantic features [+external causation] \& [+manner], i.e. if the input verb is causative, therefore transitive, and if its meaning specifies the manner in which the denoted event is realized-including a necessary instrument. It is this instrumental 
semantic participant that is lexicalised in the instrumental -oir rule (rasoir 'razor', tranchoir 'slicer; chopper').

Causative verbs (thus [+external causation]) bearing the feature [-manner] do not serve as input to the -oir rule that constructs an instrumental $\mathrm{N}$-oir, but serve as input to the -oir rule that constructs an locative N-oir (assassinoir 'lit. a place where one can be murdered/a dangerous place', lavoir 'washing place').

Intransitive verbs and transitive non-causative verbs, because they bear the feature [-external causation], do not serve as input to the instrumental -oir rule, but serve as input to the -oir rule that constructs locative N-oir (mouroir 'lit. dying place', patinoire 'skating rink'; guettoir 'place from where one can look out', regardoir 'lit. a place from where we can see'); see (25).

\section{Instrumental -age nominals}

In this section, we present the results of our investigation of the relevance of the semantic features [+external causation] and [+manner] for each base verb of instrumental -age nominals in our corpus (Sect. 4.1). The other two paragraphs of the section propose the formal representations of the morphological rule that constructs instrumental $\mathrm{N}$-age. In Sect. 4.2, we present basic theoretical assumptions on semantic sub-patterns within a morphological rule and our approach to polysemy. Finally, in Sect. 4.3, we propose the formalisation of the semantic sub-pattern of the $\mathrm{N}$-age rule which generates the instrumental nominal. For the semantic representation of the verbal base, we follow the theoretical framework of Levin and Rappaport (1995 and later).

\subsection{Evidence from the corpus data}

We investigated the relevance of [+external causation] and [+manner] semantic features in the sense of Ferret (2013) for each base verb of instrumental -age nominals in our corpus. The identified syntactic patterns of these base verbs confirm that they must indeed be transitive; the corpus contains no intransitive bases, although intransitives may serve as bases for eventive $\mathrm{N}$-age as illustrated by (34) (see Ferret and Villoing 2012 for (34), (35) and (37)).

a. passage de l'ouragan 'passing of the hurricane' (unaccusative)

b. jonglage 'juggling' (unergative)

Our results also confirm that causation is necessarily external, since no transitive verb with internal causation can serve as base for instrumental $\mathrm{N}$-age, although they may serve as bases for eventive $\mathrm{N}$-age as illustrated by (35):

a. traversage (de la rue) 'the crossing (of the street)'

b. sautage de barrières 'the jumping over fences'

The verbs in our corpus pass the test for the identification of an instrumental semantic participant in the meaning of the selected verbs: 
(36) a. Jean a garni le siège $\rightarrow$ Jean a utilisé un objet pour garnir le siège (Vrai), comme par exemple un garnissage (true).

'Jean filled the chair $\rightarrow$ Jean used an object to fill the chair (true), like stuffing for example. (true)'

$\Rightarrow$ garnir 'fill', V [+manner]

b. Jean a attelé le cheval $\rightarrow$ Jean a utilisé un objet pour atteler le cheval (Vrai), comme par exemple un attelage (true).

'Jean harnessed the horse $\rightarrow$ Jean used an object to harness the horse (True), such as a harness for example. (true)'

$\Rightarrow$ atteler 'harness', V [+manner]

c. La nurse a emmailloté le bébé $\rightarrow$ La nurse a utilisé un objet pour emmailloter le bébé (true), comme par exemple un emmaillotage (true).

'The nurse swaddled the baby $\rightarrow$ The nurse used an object to swaddle the baby (true), such as swaddling. (true)'

$\Rightarrow$ emmailloter 'swaddle', V [+manner]

d. Marie a maquillé sa fille $\rightarrow$ Marie a utilisé un objet pour maquiller sa fille (true), comme par exemple son propre maquillage (true).

'Marie put makeup on her daughter $\rightarrow$ Marie used an object to put make up on her daughter (true), such as makeup, for example. (true)'

$\Rightarrow$ maquiller 'make up', $\mathrm{V}$ [+manner]

Our results confirm that the presence of a manner component in the semantics of the verb is a must: transitive verbs with external causation (thus causative verbs) which do not include a manner component cannot produce an instrumental interpretation, but only an eventive reading, as illustrated by (37):

a. le rentrage (des vaches) 'the returning of cows'

b. le tournage (de la roue) 'the turning of the wheel'

To conclude, like the instrumental -oir rule, the instrumental -age rule selects transitive causative verbs (i.e. [+external causation] verbs) with a [+manner] semantic feature. [+external causation] and [+manner] are both necessary conditions a verb has to respect in order to be a potential base for the rule.

\subsection{Formalisation: Semantic sub-patterns and polysemy within a morphological rule}

We adopt a lexematic approach to morphology, within which the construction of lexemes is expressed through morphological rules (henceforth LCR 'Lexeme Construction Rule'), which express generalisations and establish correlations between base lexemes and constructed lexemes (Matthews 1974; Anderson 1992; Aronoff 1994; Fradin 2003; Booij 2005; for applications to French, cf. Fradin et al. 2009).

The identity of a lexeme minimally rests on three properties, which constitute the basis of a linguistic sign: phonological, syntactic and semantic. These properties are independent of each other and represented in disassociated rubrics that constitute independent dimensions, but to which morphological rules have simultaneous access (cf. Fradin 2003). The lexeme is therefore the initial and final unit of constructional 
morphology, and the rules are seen as functions that link these three properties in the base lexeme and the derived lexeme. According to this approach, affixes do not constitute "minimal" units of meaning, but are the phonological realisations of affixation rules, which are themselves associated with one or more semantic and syntactic values.

As for the semantics of the lexeme, we support the idea that morphological rules do not apply to semantically underspecified lexemes, but to fully specified bases (we follow the French approach of Fradin and Kerleroux 2003a, 2003b, 2009; Kerleroux 2004; Fradin et al. 2009). For the construction of meaning, we adopt the hypothesis that interpretation of a deverbal noun stems either from the eventuality expressed by the base verb ('event interpretation') or from one or more of its semantic participants, depending on any rule-based constraints (e.g., agent, instrument, patient, locative; for French cf. Hathout et al. 2009; Corbin 2005; Dal 1999; Plénat 2005; Roché 2003; Fradin and Kerleroux 2003a, 2003b; Kerleroux 1996, 2004). The construction of meaning for deverbal nouns denoting an object is achieved by the morphological rule through the selection of a semantic participant of the base verb. ${ }^{6}$

For the instrumental nominals studied here, we hypothesise that the verbal base contains an instrumental semantic participant that is nominalised by the morphological rule. In other words, the formation of nouns with an instrumental reading requires a base verb that follows certain semantic conditions such as having an instrumental semantic participant. In this sense, we subscribe to an approach wherein the interpretation of a deverbal noun is predictable from the semantic properties of the verbal base. $^{7}$

We've shown in Sect. 4.1 that the instrumental reading of $\mathrm{N}$-age is really dependant on the semantic properties of the base verb that enters the suffixation rule. Following this illustration, we propose below a formalisation of the instrumental semantic sub-pattern of the $\mathrm{N}$-age rule.

We propose that -age suffixation in French involves a single morphological rule that encompasses all possible readings (roughly, event, locative, instrument, patient, cf. Tribout and Villoing (2013) for the various interpretations), instead of assuming multiple homonymous rules (cf. Table 1). This choice follows the principle of economy, because a part of the rule, which carries phonological and syntactic information, is shared by all -age nouns (Fradin and Kerleroux's 2003a, 2003b concept of Flexème).

Semantically, the N-age rule divides into a range of sub-patterns: one pattern for the event reading (cf. Ferret and Villoing 2012), and another (or others) for the concrete object readings.

Consequently, the various readings of the derivations do not stem from a single semantic interpretation, but are constructed in parallel according to the instructions

\footnotetext{
${ }^{6}$ This idea of "nominalisation of an argument" was initially proposed by Williams (1981) in a syntactic analysis of English nouns taking the suffix -able, and taken up by morphologists like Booij $(1988,1992)$, in the treatment of Dutch -er nouns.

${ }^{7}$ Recent work in this approach shows that some readings of deverbal nouns depend on the semantic properties of the verbal bases. Thus, the product reading of nominalisations is only possible with telic verbal bases that express the creation, reproduction or modification of an object (Bisetto and Melloni 2007), the state reading correlates with the existence of a spatial construction (Fradin 2011) and the method reading is associated with stative base verbs (Fradin 2012a).
} 
Table 1 The N-age suffixation rule

\begin{tabular}{lll}
\hline & INPUT & OUTPUT \\
\hline Phonology & Verbal stem & Verbal stem $\oplus / \mathrm{az} /$ \\
Syntax & Cat: V & Cat : N \\
Semantics & Event structure & $\bullet$ Event \\
& & $\bullet$ Concrete object $^{\mathrm{a}}$ \\
& & - Instrument $^{\prime}$ \\
& & - Locative \\
& & - Patient \\
\hline
\end{tabular}

${ }^{a}$ Although frequent, the result reading of $\mathrm{N}$-age is not one of the rule-based readings, but the result of polysemy because it does not correspond to the nominalisation of a semantic participant

in the various sub-patterns, selecting the event as a whole, or different semantic participants, and therefore requiring verbal bases with specific semantic properties.

The sub-pattern that interests us, the instrumental pattern, is one of the semantic sub-patterns that form concrete object nouns.

\subsection{Formalisation: The instrumental reading of the -age rule}

We adopt the theoretical framework of Levin and Rappaport (1995, and following) for the representation of verbal predicate meaning, and their approach to the lexicon/syntax interface (the projectionist approach). Following Ferret et al. (2010), Ferret and Villoing (2012) and Ferret (2013), we propose that the morphological rule forming deverbal nouns selects the event structure of the base verb, i.e. the lexicosemantic part of the verbal predicate, whether it is the basis for the construction of an event nominal (le cambriolage 'the break-in') or for the nominalisation of a semantic participant of the verbal event structure (the $\mathrm{N}$-age cases considered here; see also other semantic participants, such as instrumental $\mathrm{N}$-oir and $\mathrm{N}$-eur). ${ }^{8}$

\subsubsection{The semantic representation of the base verb}

Levin and Rappaport's theoretical framework distinguishes two levels of verbal representation:

- a lexico-semantic level, which defines the event structure of the verb;

- a lexico-syntactic level, which defines the argument structure of the verb.

The argument structure of a verb is derived from the event structure of that verb through the application of Linking Rules (initially proposed by Carter 1977), which associate the semantic participant(s) present in the event structure (as variables) with an external argument position (Immediate Cause Linking Rule) and/or with a direct internal argument (Directed Change Linking Rule) ${ }^{9}$ (for other Linking Rules and

\footnotetext{
${ }^{8}$ See also in another theoretical framework, Pustejovsky (1995).

${ }^{9}$ So, the syntactically-relevant semantics of the verb is also morphologically relevant in the formation of deverbal N. So, beyond serving as input for the rules producing argument structure, event structure also serves as input for the morphological rule.
} 
details see Levin and Rappaport 1995, 2000). The event structure is used to avoid the need for thematic roles in the argument structure, shown to be problematic in the literature (see in particular, Dowty 1989, 1991).

The event structure of a verbal predicate consists of a decomposition of lexical meaning through primitive semantic predicates: ACT, CAUSE, etc. (following Jackendoff 1983, 1990; see Lexical Conceptual Structures in his theory of Conceptual Semantics), and through variables representing the semantic participants licensed either by the verbal root - that provides the idiosyncratic meaning of the predicateand the event structure template, or by the verbal root alone (see below).

Event structure also determines the lexico-aspectual class of the predicate (Vendler 1957): state, activity, accomplishment or achievement (see also Dowty 1979), and Van Valin (1991) in the framework of Role and Reference Grammar).

The verbal root inserted into the event structure is represented by capitals in angle brackets. The root appears either as a modifier of a primitive semantic predicate, as in the ACT templates (38), or as its structural argument (39). In (39), the predicate BECOME takes a State (39a) or a Locative (39b) as structural arguments:

$$
\text { [X ACT }<\text { COURIR }>\text { ]: courir 'run' }
$$
a. [BECOME y $<$ MORT $>$ ]: mourir 'die'
b. [[x ACT] CAUSE [y BECOME <PLACE $>]]$ : poser quelque chose quelque part 'put something somewhere'

The variables $(x, y$ or $z$ ) represent the semantic participants licensed by the verbal root and generally correspond to the participants imposed by the event structure template. Exceptions are verbs whose semantic participants are licensed by the verbal root alone. This is the case, according to Levin and Rappaport (1999), of surface contact verbs such as Eng. wipe, which can be found in both intransitive and transitive patterns: John wiped. John wiped the table. The participant licensed by the verbal root alone is underlined: [x ACT <WIPE $>$ y]; it is therefore optional in the argument structure of the verb.

An event structure can be simple ((38) and (39a)) or complex (for causative verbs alone, (39b) and (40)). A complex event structure contains two sub-events: the first, CAUSE, is a trigger, leading to the realisation of the event and of the 'triggered' subevent: e.g. change of state (casser 'break', sécher 'dry') (40a) or change of location (mettre 'put', placer 'place') denoted by the verb in (40b). ${ }^{10}$

$$
\begin{aligned}
& \text { a. [[x ACT }] \text { CAUSE }[\text { y BECOME }<\text { STATE }>]] \\
& \text { b. [[X ACT] CAUSE [y BECOME }<\text { PLACE }>]]
\end{aligned}
$$

Thus, our analysis of deverbal $\mathrm{N}$ uses the event structure of the verbal predicate as a derivational base.

\footnotetext{
${ }^{10}$ For Levin and Rappaport, only accomplishments are causative. We propose (following, among others, Ferret and Villoing 2012, and Ferret 2013), to take into account for all causative verbs, whether they denote a state (John scared Mary), an activity (John rolled the ball) or an achievement (They exploded the bomb), using the same complex structure, in which the embedded part of the event structure changes (that is, respectively: [x CAUSE [y <SCARED $>$ ]]]; . [x CAUSE [y ACT < ROLL $>$ ]] and [x CAUSE [y BECOME[-DURATIVE] $<$ EXPLODED. $>$ ]]]).
} 


\subsubsection{Formalisation of the instrumental -age rule}

The instrumental -age rule selects causative verbs, i.e. transitive verbs with external causation [+external causation], whose meaning implies the obligatory presence of an instrument (i.e. a [+manner] verb). Hence, following Ferret's (2013) analysis, we propose that the rule selects as input a verb having the event structure (41) and lexicalizes $\underline{z}$ as $\mathrm{N}$ instrument:

$[[\mathrm{x}$ ACT $<$ USE $>\underline{\mathrm{z}}]$ CAUSE $[\alpha]]$, where $[\alpha]$ denotes a change of state (ex. accomplishment or achievement), an activity or a state

As shown in (41), the semantic feature [+external causation] of the verb is expressed by the primitive semantic predicate CAUSE and the semantic feature [+manner] is encoded by both the lexical semantic root $<$ USE $>$ and the semantic participant $\underline{z}$ (instrument) licensed by $<$ USE $>$. The variable $z$ is underlined as it is a semantic participant licensed by the root, but not by the event structure template.

In (41), two lexical semantic roots represent the meaning of the verb: the first is $<$ USE $>$ (the meaning of the verb defines the manner in which the 'causing event' is realised: through the use of an instrument, $z$ ), and the second root is in $[\alpha]$, with $\alpha$ denoting a change of state verb, or a state or an activity. The two semantic roots are lexicalised through a single verb (see also Beavers and Koontz-Garboden 2012 contra Levin and Rappaport 2006, 2008, 2011).

We propose to formalize the instrumental interpretation of the -age rule as in (42).

$$
\begin{aligned}
& \text { Formation of instrumental N-age } \\
& \qquad \mathrm{v}[[\mathrm{x} \text { ACT }<\text { USE }>\underline{\mathrm{z}}] \text { CAUSE }[\alpha]] \rightarrow \mathrm{N} \text {-age denoting an instrument }
\end{aligned}
$$

For the verbs from our corpus, the instrumental -age rule select causatives verbs with three different event structures: one denoting accomplishments (43), one denoting achievements (45) and one denoting states (47).

(43) provides the event structure of causative accomplishment verbs, as in emmailloter 'swaddle' in (44). ${ }^{11}$

$$
\begin{aligned}
& \text { [[x ACT <USE }>\underline{z} \text { ] CAUSE [ y BECOME [+DURATIVE] }<\text { STATE }>\text { ]] } \\
& \text { a. emmailloter 'swaddle': }
\end{aligned}
$$

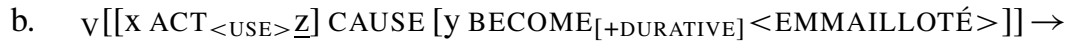

The following verbs from our corpus exhibit this event structure: adoucir 'soften', atteler 'harness', bander 'bandage', blinder 'shore up, timber', border 'plank, plate', bourrer 'stuff', calfeutrer 'make draughtproo', camoufler 'camouflage', carreler 'tile', capitonner 'pad', cirer 'polish', emballer 'wrap up', enrober 'coat', entoiler 'cover', envelopper 'wrap', garnir 'fill/stuff', gommer 'scrub', maquiller 'make up', plomber 'fill', rembourrer 'stuff' and remplir 'fill'.

\footnotetext{
${ }^{11}$ Where [+DURATIVE] specifying the semantic predicate BECOME, is proposed to distinguish accomplishment change of state verbs from achievement verbs which are then [-DURATIVE] as in (46), see Ferret (2013) for details.
} 
The rule can also select a verb with the event structure (45), that is a causative verb denoting an achievement, as in allumer 'ignate' (46) or embrayer 'let in the clutch', aiguiller 'change the points, switch' in our corpus.

[[x ACT <USE $>\underline{z}]$ CAUSE [y BECOME [-DURATIVE] $<$ STATE $>$ ]]

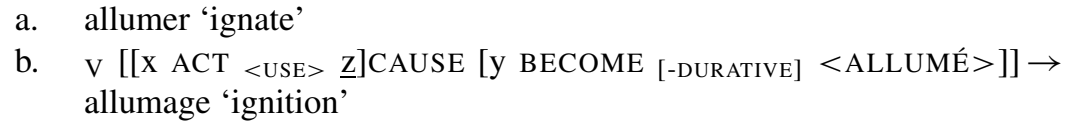

Finally the rule can also select a verb with the event structure in (47), that is a causative verb denoting a state, as in barrer 'block' (48), or voiler 'veil'/voilage 'veil' in our corpus:

$$
\begin{aligned}
& {[[\mathrm{x} \text { ACT }<\text { USE }>\text { z }] \text { CAUSE }[\mathrm{y}<\text { STATE }>]]} \\
& \text { a. barrer 'block' } \\
& \text { b. } \quad[[\mathrm{x} \text { ACT }<\text { USE }>\underline{z}] \text { CAUSE }[y<\text { BARRÉ }>]] \rightarrow \text { barrage 'dam' }
\end{aligned}
$$

Thus, as with instrumental N-oir, it is the semantic participant $z$ that is selected by the rule in order to construct a $\mathrm{N}$-age Instrument. In both rules, the instrumental $\mathrm{N}$ realises a semantic participant lexically entailed by the causative base verb.

\section{Conclusion}

Although all deverbal nouns in our corpus may have an event reading, we have shown that the instrument reading of the nominalising -age suffixation rule does not derive semantically from the prototypical event interpretation of this rule. Instead, the instrument interpretation of the -age rule depends on the semantic properties of the verbal base, which must include the features [+external causation] and [+manner]. This analysis allows us to predict whether neologisms with -age would have an instrumental interpretation or not.

The -age suffixation rule obeys the same constraints as -oir suffixation (which prototypically produces instrument nominals) as defined by Ferret (2013). Consequently, we must consider the possibility that -age suffixation, like the $\mathrm{N}$-oir rule, is a morphological rule that involves various semantic sub-patterns that allow the construction of nouns with a range of readings.

In addition, we have proposed a formalisation of the instrumental semantic subpattern for -age.

On the basis of our study of -age nominals, we were able to propose a new approach to the polysemy of deverbal nouns. Rather than considering the multiple readings of deverbal nouns as the result of systematic semantic drift, through metonymy or metaphor, we argue that the morphological rule itself is composed of multiple semantic sub-patterns, constructing nominal readings through 'nominalising' a semantic participant of the base verb, in accordance with its semantic properties. This polysemous approach to morphological rules can also account for semantic properties shared by several morphological rules (cf. the instrumental semantic sub-pattern forming deverbal nouns with -age and -oir). 
The proposed constraints on the formation of instrumental deverbal nominals must be confirmed through the study of morphological categories which are more widely attested in corpora than -age, such as -eur, verb-noun compounds and verb to noun conversions. In light of this hypothesis, it is also necessary to examine derivations with -ment (pansement 'bandage', déguisement 'disguise') and -ion (aération 'ventilation', climatisation 'air conditioning', ventilation 'ventilation'), which are in competition with -age suffixation, to determine whether and under what constraints other event nominalisation rules are susceptible to forming instrumentals, as appears from the data in TLFI.

Acknowledgements We sincerely thank the editors and reviewers for their valuable comments, which contributed to the improvement of our first version. We also wish to extend our gratitude to the organisers and participants of the Workshop Semantics of derivational morphology: Empirical evidence and theoretical modeling (Dusseldorf, July 2014), as well as to the members of UMR 7023 (University of Paris 8) and the participants of the JeNOM5 Workshop (Barcelona, June 2013), who commented on an earlier version of this study. Special thanks to Dana Cohen for her valuable help with the English.

Open Access This article is distributed under the terms of the Creative Commons Attribution 4.0 International License (http://creativecommons.org/licenses/by/4.0/), which permits unrestricted use, distribution, and reproduction in any medium, provided you give appropriate credit to the original author(s) and the source, provide a link to the Creative Commons license, and indicate if changes were made.

\section{References}

Anderson, S. R. (1992). A-morphous morphology. Cambridge: Cambridge University Press.

Aronoff, M. (1994). Morphology by itself. Cambridge: MIT Press.

Beavers, J., \& Koontz-Garboden, A. (2012). Manner and result in the roots of verbal meaning. Linguistic Inquiry, 43, 331-369. [Prepublication draft 2011].

Benveniste, E. (1966 [1974]). Problèmes de linguistique générale (Vol. 1). Paris: Gallimard.

Bisetto, A., \& Melloni, C. (2007). Result nominals: a lexical-semantic investigation. In G. Booij, B. Fradin, E. Guevara, S. Scalise, \& A. Ralli (Eds.), On-line proceedings of the Fifth Mediterranean Morphology Meeting (MMM5) Fréjus 15-18 September 2005 (pp. 393-412). Bologne: Morbo Università di Bologna.

Booij, G. (1986). Form and meaning in morphology, the case of Dutch agent nouns. Linguistics, 24, 503518.

Booij, G. (1988). The relation between inheritance and argument linking: deverbal nouns in Dutch. In M. Everaert et al. (Eds.), Morphology and modularity (pp. 57-73). Dordrecht: Foris.

Booij, G. (1992). Morphology, semantics, and argument structure. In I. Roca (Ed.), Thematic structure, its role in grammar (pp. 27-50). Dordrecht: Foris.

Booij, G. (2005). The grammar of words: an introduction to linguistic morphology. Oxford: Textbooks in Linguistics.

Booij, G. (2007). Polysemy and construction morphology. In F. Moerdijk, A. van Santen, \& R. Tempelaars (Eds.), Leven met woorden (pp. 355-364). Leiden: Institut voor Nederlandse Lexicologie.

Booij, G., \& Lieber, R. (2004). On the paradigmatic nature of affixal semantics in English and Dutch. Linguistics, 42, 327-357.

Cadiot, P. (1991). A la hache ou avec la hache? Représentation mentale, expérience située et donation du référent. Langue Française, 91, 7-23.

Carter, R. J. (1977). Toward a linking grammar of English. Recherches Linguistiques de Vincennes, 4, 13-31.

Corbin, D. (2005). French (Indo European: Romance). In G. Booij, C. Lehmann, J. Mudgan, \& S. Skopeteas (Eds.), Morphology. An international handbook on inflection and word formation (Vol. 2, art. 121, pp. 1285-1299). Berlin/New York: Walter de Gruyter.

Corbin, D. (2015, to appear). Le lexique construit. Paris: Armand Colin. 
Corbin, D., \& Temple, M. (1994). Le monde des mots et des sens construits: catégories sémantiques, catégories référentielles. Cahiers de Lexicologie, 65, 213-236.

Dal, G. (1999). Suffixation par -et(te) et bases verbales. In D. Corbin, G. Dal, B. Fradin, B. Habert, F. Kerleroux, M. Plénat, \& M. Roché (Eds.), La morphologie des dérivés évaluatifs, Forum de morphologie ( $2^{e ̀ m e s}$ rencontres), Silexicales 2, Villeneuve d'Ascq/Toulouse (pp. 37-47).

Darmesterter, A. (1877). De la création actuelle des mots nouveaux dans la langue française et des lois qui la régissent. Paris: F. Vieweg.

Dressler, W. U. (1980). Universalien von Agens-Wortbildungen. In G. Bretschneider \& C. Lehmann (Eds.), Wege zur Universalienforschung: sprachwissenschafliche Beiträge zum 60. Geburtstag von Hansjakob Seiler, Tübingen, Narr (pp. 110-114).

Dressler, W. U. (1986). Explanation in natural morphology: illustrated with comparative and agent-noun formation. Linguistics, 24, 519-548.

Dowty, D. (1979). Word meaning and Montague Grammar. Dordrecht: Reidel.

Dowty, D. (1989). On the semantic content of the notion 'thematic role'. In G. Chierchia, B. Partee, \& R. Turner (Eds.), Property theory, type theory and natural language semantics (pp. 69-129). Dordrecht: Reidel.

Dowty, D. (1991). Thematic proto-roles and argument selection. Language, 67(3), 547-619.

Dubois, J. (1962). Etude sur la dérivation suffixale en français moderne et contemporain. Paris: Larousse.

Ferret, K. (2013). Semantic propertie(s) of the base verbs and locative or instrumental interpretation of Noir(e). In 9th Mediterranean Morphology Meeting, University of Zagreb, Dubrovnik, 15-17 September 2013 .

Ferret, K., \& Villoing, F. (2012). L'aspect grammatical dans les déverbaux en -age et -ée. Lexique, 20, 73-127.

Ferret, K., Soare, E., \& Villoing, F. (2010). Rivalry between French -age and -ée: the role of grammatical aspect in nominalization. In M. Aloni, H. Bastiaanse, T. De Jager, \& K. Schultz (Eds.), Lecture Notes in Computer Science: Vol. 6042. Logic, Language and Meaning, 17th Amsterdam Colloquium, The Netherlands, December 2009, Revised Selected Papers (pp. 284-295). Berlin: Springer.

Fradin, B. (2003). Nouvelles approches en morphologie. Paris: PUF.

Fradin, B. (2005). On a semantically grounded difference between derivation and compounding. In W. U. Dressler, D. Katovsky, O. E. Pfeiffer, \& F. Rainer (Eds.), Morphology and its demarcations (pp. 161182). Amsterdam/Philadelphia: John Benjamins.

Fradin, B. (2011). Remarks on State denoting nominalizations. Recherches Linguistiques de Vincennes, 40, 73-99.

Fradin, B. (2012a). Les nominalisations et la lecture 'moyen'. Lexique 20, 125-152.

Fradin, B. (2012b). Sur la corrélation existant entre les suffixes -age et -ment et les distinctions sémantiques observables dans les nominalisations du français. NOMICO 7 septembre 2012.

Fradin, B., \& Kerleroux, F. (2003a). Quelles bases pour les procédés de la morphologie constructionnelle? In B. Fradin, G. Dal, N. Hathout, M. Plénat, \& M. Roché (Eds.), Les unités morphologiques, Vol. 3, Silexicales (pp. 76-84). Villeneuve d'Ascq, SILEX: CNRS \& Université Lille 3.

Fradin, B., \& Kerleroux, F. (2003b). Troubles with lexemes. In G. Booij, J. de Cesaris, S. Scalise, \& A. Ralli (Eds.), Topics in morphology. Selected papers from the Third Mediterranean Morphology Meeting, Barcelona, September 20-22, 2001 (pp. 177-196). Barcelona: IULA-Universitat Pompeu Fabra.Barcelona.

Fradin, B., \& Kerleroux, F. (2009). L'identité lexémique. In B. Fradin, F. Kerleroux, \& M. Plénat (Eds.), Aperçus de morphologie du français (pp. 83-102). Saint-Denis: Presses Universitaires de Vincennes.

Fradin, B., Kerleroux, F., \& Plénat, M. (2009). Aperçus de morphologie du français. Saint-Denis: Presses Universitaires de Vincennes.

Fradin, B., \& Winterstein, G. (2012). Tuning agentivity and instrumentality: deverbal nouns in -oir revisited. In Décembrettes 8, Bordeaux, December 6-7, 2012.

Grimshaw, J. (1990). Argument structure. Cambridge: MIT Press.

Haarmann, H. (1975). Polyfunktionale Suffixe im Spanischen. In Filología y didáctica hispánica. Homenaje al profesor Hans-Karl Schneider (pp. 87-114). Hamburg: Buske.

Hathout, N., Namer, F., Plénat, M., \& Tanguy, L. (2009). La collecte et l'utilisation des données en morphologie. In B. Fradin, G. Dal, N. Hathout, M. Plénat, \& M. Roché (Eds.), Aperçus de morphologie du français (pp. 267-287). Saint-Denis: Presses Universitaires de Vincennes.

Jackendoff, R. (1983). Semantic and cognition. Cambridge: MIT Press.

Jackendoff, R. (1990). Semantic structures. Cambridge: MIT Press.

Kelling, C. (2001). Agentivity and Suffix Selection. In M. Butt \& T. H. King (Eds.), Proceedings LFG 2001 (pp. 147-162). Stanford: CSLI Publications. 
Kerleroux, F. (1996). La coupure invisible. Lille: Presses Universitaires du Septentrion.

Kerleroux, F. (2004). Sur quels objets portent les opérations morphologiques de construction ? Lexique, $16,85-123$.

Koenig, J. P., Mauner, G., \& Bievenue, B. (2007). What with? The anatomy of a (Proto)-Role. Journal of Semantics, 25, 175-220.

Levin, B. (1993). English verb class and alternations: a preliminary investigation. Chicago: University of Chicago Press.

Levin, B., \& Rappaport, M. (1995). Unaccusativity. Cambridge: MIT Press.

Levin, B., \& Rappaport, M. (1999). Two structures for compositionally derived events. SALT, 9, 199-223.

Levin, B., \& Rappaport, M. (2000). Classifying single argument verbs. In P. Coopmans, M. Everaert, \& J. Grimshaw (Eds.), Lexical specification and insertion (Vol. 17, pp. 269-304). Amsterdam: John Benjamins.

Levin, B., \& Rappaport, M. (2006). Constraints on the complexity of verb meaning and VP structure. In H.-M. Gaertner, R. Eckardt, R. Musan, \& B. Stiebels (Eds.), Between 40 and 60 puzzles for Krifka, Berlin: ZAS.

Levin, B., \& Rappaport, M. (2008). Lexicalized meaning and the internal temporal structure of events. In S. Rothstein (Ed.), Theoretical and crosslinguistic approaches to the semantics of aspect (pp. 13-42). Amsterdam: John Benjamins.

Levin, B., \& Rappaport, M. (2011). Lexicalized Meaning and Manner/Result Complementarity, ms.

Martin, F. (2010). The semantics of eventive suffixes in French. In A. Alexiadou \& M. Rathert (Eds.), The semantics of nominalizations across languages and frameworks (pp. 109-140). Berlin: de Gruyter.

Matthews, P. (1974). Morphology. Cambridge: Cambridge University Press.

Meyer-Lübke, W. (1890-1906). Grammaire des langues romanes, Tome II, « Morphologie ». Slatkine Reprints, Genève (1974).

Namer, F., \& Villoing, F. (2008). Interpréter les noms déverbaux: quelle relation avec la structure argumentale du verbe de base ? Le cas des noms en -oir(e) du français. In J. Durand, B. Habert, \& B. Laks (Eds.), Actes du ler Congrès Mondial de Linguistique Française (CMLF 2008), Paris, 9-12 juillet 2008 (pp. 1551-1569). Paris: EDP Sciences.

Panagl, O. (1975). Kasustheorie und Nomina agentis. In H. Rix (Ed.), Flexion und Wortbildung, Wiesbaden, Reichert (pp. 232-246).

Plénat, M. (2005). Rosinette, cousinette, starlinette, chipinette. Décalage, infixation et épenthèse devant -ette. In I. Choï-Jonin, M. Bras, A. Dagnac, \& M. Rouquier (Eds.), Mélanges offerts au Professeur Christian Molinier. Questions de classification en linguistique: méthodes et descriptions (pp. 275298). Berne: Peter Lang.

Pustejovsky, J. (1995). The generative lexicon. Cambridge: MIT Press.

Rainer, F. (2005). Typology, diachrony, and universals of semantic change in word formation: a romanist's look at the polysemy of agent nouns. In G. Booij, A. Ralli, S. Scalise, \& S. Sgroi (Eds.), Morphology and linguistic typology. On-line proceedings of the Fourth Mediterranean Morphology Meeting (pp. 21-34). Catania: University of Catania, Faculty of Letters.

Rappaport Hovav, M., \& Levin, B. (1992). Er nominals: implications for the theory of argument structure. In T. Stowell \& E. Wehrli (Eds.), Syntax and Semantics: Vol. 26. Syntax and the Lexicon (pp. 127153). New York: Academic Press.

Roché, M. (2003). L'interfixe est-il une unité morphologique ? In B. Fradin, G. Dal, N. Hathout, F. Kerleroux, M. Plénat, \& M. Roché (Eds.), Silexicales 3. Les unités morphologiques, Actes du 3e Forum International de Morphologie, Villeneuve d'Ascq, 19-21 septembre 2002 (pp. 169-178). Lille: Université Lille 3, SILEX.

Rosenberg, M. (2011). The polysemy of agent nouns: diachronic, synchronic and contrastive evidence from French and Swedish STUF-Language Typology and Universals, 64(1), 53-64.

Ryder, M. E. (1990). Mixers, mufflers and mousers: The extending of the -er suffix as a case of prototype reanalysis. Berkeley Linguistic Society, 17, 299-311.

Sleeman, P., \& Verheugd, E. (2004). Action and Agent Nouns in French and Polysemy. In D. Willems, B. Defranq, T. Colleman, \& D. Noël (Eds.), Contrastive Analysis in Language: Identifying Linguistic Units of Comparison (pp. 137-154). Hampshire, New York: Palgrave Macmillan.

Talmy, L. (1975). Semantics and syntax of motion. In J. Kimball (Ed.), Syntax and semantics 4 (pp. 181238). New York: Academic Press.

Tribout, D. (2010). Les conversions de nom à verbe et de verbe à nom en français. Thèse de doctorat, Université Paris-Diderot-Paris 7.

Tribout, D., \& Villoing, F. (2012). Verb > noun conversion and verb-noun compounding in French: a case of morphological rivalry. In Décembrettes 8 , Bordeaux. 
Tribout, D., \& Villoing, F. (2013). The polysemy of French deverbal nouns in light of -age suffixation. In 9th Mediterranean Morphology Meeting, University of Zagreb, Dubrovnik, 15-17 September 2013.

Tribout, D., \& Villoing, F. (2014). Composition VN, conversion V > N: une distribution complémentaire dans la morphologie du français ? In F. Villoing, S. David, \& S. Leroy (Eds.), Foisonnements morphologiques. Etudes en hommage à Françoise Kerleroux (pp. 75-108). Nanterre: Presses Universitaires de Paris Ouest.

Uth, M. (2010). The rivalry of French -ment and -age from a diachronic perspective. In A. Alexiadou \& M. Rathert (Eds.), The semantics of nominalizations across languages and frameworks (pp. 215-244). Berlin/New York: Mouton de Gruyter.

Uth, M. (2011). Französische Ereignisnominalisierungen. Abstrakte Bedeutung und regelhafte Wortbildung. Berlin/New York: de Gruyter.

Van Valin, R. (1991). Semantic parameters of split intransitivity. Language, 66, 221-260.

Vendler, Z. (1957). Verbs and times. Philosophical Review, 66(2), 143-160.

Villoing, F. (2009). Les mots composés VN. In B. Fradin, F. Kerleroux, \& M. Plénat (Eds.), Aperçus de morphologie du français (pp. 175-198). Saint-Denis: Presses Universitaires de Vincennes.

Villoing, F. (2012). French compounds, Probus. International Journal of Latin and Romance Linguistics, 24(1), 29-60. Amsterdam: Mouton de Gruyter.

Williams, E. (1981). On the notions 'lexically related' and 'head of a word'. Linguistic Inquiry, 12(2), 245-274.

Winther, A. (1975). Note sur les formations déverbales en -eur et en -ant. Cahiers de lexicologie, XXVI, 56-84.

Trésor de la Langue Française (1971-1994). Dictionnaire de la langue du XIXe et du XXe siècle, 16 volumes, CNRS, Gallimard, Paris. (TLFi: http://atilf.atilf.fr/tlf.htm et CDROM: CNRS édition, 2004.) 